\title{
TOURISM IN POLAR REGIONS AND THE SUB-ANTARCTIC ISLANDS
}

\author{
by Denise Landau
}

(with one text-figure and one table)

\begin{abstract}
Landau, D. 2007 (23:xi): Tourism in polar regions and the sub-Antarctic islands. Papers and Proceedings of the Royal Society of Tasmania 141(1): 173-1 80. https://doi.org/10.26749/rstpp.141.1.173 ISSN 0080-4703. International Association of Antarctica Tour Operators (IAATO), PO Box 2178, Basalt, CO 81621, USA.
\end{abstract}

\begin{abstract}
Tourism in the Antarctic is coordinated by the International Association of Antarctica Tour Operators (IAATO) which has regular meetings with the Antarctic Treaty parties. It keeps full records of visitation to the Antarctic and develops guidelines for the conduct of tourist activities so that the needs of tourists, the science community and the Antarctic environment are cared for. The sub-Antarctic has not been a major tourist destination or regulatory focus for IAATO as most sub-Antarctic islands are under national jurisdiction; thus visits to this region are either on the way to or from the Antarctic. Considerable visitation to the sub-Antarctic is conducted by non-IAATO operators. Statistics equivalent to those collected for the Antarctic are not available through IAATO; however, many of the IAATO guidelines are relevant to sub-Antarctic activities. This paper outlines IAATO's history, its guidelines and issues for the future.
\end{abstract}

Key Words: tourism, Antarctic, sub-Antarctic, IAATO, impacts.

\section{INTRODUCTION}

Without the vision of Lars-Eric Lindblad, a tourism pioneer from Sweden, tourism in the sub-Antarctic islands and the Antarctic might not have begun when it did. Lindblad saw a market for tourism that coupled adventure travel with education as a primary theme, as well as a focus on the preservation of the environment, particularly its wildlife. As a result, the 100-passenger vessel Lindblad Explorer was built for its first cruise to Antarctica in 1970. Tourism to the sub-Antarctic and the Antarctic has evolved without any significant environmental incidents for nearly 40 years. This paper reviews the history and evolution of tourism to the sub-Antarctic and Antarctic as a contribution to the understanding of the importance to the sub-Antarctic of a new and growing industry.

As awareness of the polar regions grew, the industry expanded and more vessels and operators appeared in the Antarctic. The sphere of operation included not only relatively short cruises from gateway ports in South America, but also cruises in the Ross Sea and East Antarctica south of Australia and New Zealand. Vistas of the Transantarctic Mountains and historic huts on Ross Island and Cape Adare were, and still are, the primary features on itineraries, but added attractions are Macquarie Island and the sub-Antarctic islands of New Zealand, all of which offer extensive wildlife experiences. The advent of Russian icebreakers with onboard helicopters in the 1992-1993 austral summer added to the ability to access new island groups in the Indian Ocean (Îles Crozet, Îles Kerguelen, Heard Island), plus coastal areas of Antarctica. Here an icebreaker is needed to visit remote areas such as Emperor Penguin (Aptenodytes forsteri Gray, 1844) colonies, research stations and Taylor Valley, one of the dry valleys in southern Victoria Land that would otherwise be inaccessible. An added achievement was the first-ever circumnavigation of Antarctica by a tourist vessel - the Russian icebreaker Kapitan Khlebnikov — in the 1996-1997 season. Visits to sub-Antarctic islands remain highlights of itineraries of the tour ships using the gateway ports in Australia and New Zealand. A fly-over form of tourism using Boeing 747-400 aircraft is a popular attraction for tourists, and enables them to see coastal features south of Australia and New Zealand and in the Ross Sea, using Australia as a base for the fly-overs. No landings are made in these "scenic-only" flights. These flights occasionally allow a view of sub-Antarctic islands such as Macquarie Island and the Balleny Islands.

Ship-borne tourism added a new dimension to Antarctic activity in the early 1990s with the introduction of a variety of tour vessels — such as ice-strengthened vessels and a powerful icebreaker - capable of travelling in ice-filled waters. As the industry grew, appropriate management strategies evolved in response to the fragile environment of Antarctica and the need to protect it. The history of IAATO and its development, particularly the evolution of management strategies in response to perceived needs, was summarised by Splettstoesser \& Folks (1994), Splettstoesser (2000) and Landau \& Splettstoesser (2007).

The need for a coalition of tour companies became apparent in the early 1990s; the seven operators in Antarctica united in 1991 to form the International Association of Antarctica Tour Operators (IAATO). Competition was replaced by cooperation, and the pool of knowledge and collective experience of those founder members has become the secret of its success. As membership increased with new operators, a single voice was needed to speak for the industry, as a participant at the Antarctic Treaty Consultative Meetings (ATCMs) and other important venues where tourism issues have become major subjects of discussion. The current membership of 97 (2007), represents activities in ship-borne tourism together with one operator offering adventure tourism in the interior of Antarctica. Members come from 15 countries plus the Falkland Islands/Islas Malvinas, and comprise a variety of organisations and operators, including ship owners, land-based and fy/cruise operations, ship agents, suppliers, conservation groups, governments and specialised adventure operators. From initial small beginnings, consisting of small expedition ships or small boat operations for shore visits and cruises, there are presently some 50 vessels, including small yachts, icestrengthened ships, large ships carrying as many as several thousand passengers (but without landings), fly-overs for scenic viewing without landings, and ship-based adventure tourism. This last type of tourism includes skiing, camping, 
mountaineering, kayaking, small boat cruising (Zodiac, Naiad, Polar Cirkle), helicopter operations and SCUBA diving. Specialised guidelines have been compiled for these activities and others to ensure that all activities will have no more than a minor or transitory impact on the Antarctic environment (IAATO 2007a). Visits to scientific stations are a relatively common feature on itineraries, with rigid guidelines which tour operators must follow in order to conduct orderly visits without interfering with science activities.

Many of these activities also relate to the Arctic and other parts of the world; when tour businesses cannot operate in Antarctica (from November to March) they are conducting cruises and expeditions in other parts of the globe. Statistics from Antarctic itineraries are monitored through a system of post-visit reports, and the resulting statistics are maintained in a database that includes numbers of passengers and crew, and nationalities of all visitors. These data become part of the IAATO reporting system presented as Information Papers at Antarctic Treaty Consultative Meetings. These can be viewed on the IAATO website (IAATO 2007a) by following the link labelled "Information Papers". A comparable system for the sub-Antarctic islands is discussed below, and the Falkland Islands/Islas Malvinas will be included in the reporting system and database soon.

The types of guidelines mentioned are included on the IAATO website (IAATO 2007a). Some are posted on the open pages although the majority are on the members-only website. They have also been applied to the itineraries of operators that include visits to sub-Antarctic islands to view wildlife and undertake station visits (e.g., Macquarie, Kerguelen, Crozet, South Georgia). Frequency of visits to islands and other sites listed here are recorded using information tabulated from post-visit reports from the Antarctic Treaty area, and also from operators' printed itineraries. At the eighteenth Annual General Meeting of IAATO held in Hobart, Tasmania, in 2007, IAATO members agreed that their basic operating procedures, as specified in IAATO bylaws and guidelines, would also be applied north of latitude $60^{\circ} \mathrm{S}$ to the boundary of the Antarctic Convergence, or Polar Front, in order to include the area of jurisdiction of The Conservation of Marine Living Resources (CCAMLR), thus strengthening efforts to protect the Antarctic environment. This northward boundary would thus include South Georgia, Îles Kerguelen and Heard Island.

\section{GLOBAL RANGE OF SUB-ANTARCTIC TOURISM}

The popular attractions provided by ship-borne tourism in the Antarctic Peninsula and Ross Sea area, offshore island groups in the Treaty area and many sub-Antarctic islands comprise an important aspect of the range of tour operators' activities, many of them under Treaty party jurisdiction. Commonly visited islands in the Antarctic Treaty area include the South Shetland Islands, which take in Elephant Island and Deception Island. Less frequently visited islands in the Treaty area include the South Orkney Islands, Balleny Islands, Scott Island and Peter I Island. Islands outside the Treaty area visited occasionally or frequently include Macquarie Island (Australia), Campbell Island (New Zealand), Enderby Island (New Zealand), Auckland Islands (New Zealand) and Snares Islands (New Zealand) (the latter involving small boat cruising only, no landings). Others that have been visited in the past include Chatham Island (New Zealand) Heard Island (Australia), Îles Kerguelen (France), Amsterdam Island (France), Saint Paul Island (France), Îles Crozet (France) South Sandwich Islands (United Kingdom), Tristan da Cunha (United Kingdom), Nightingale Island (United Kingdom), Bouvetøya (Norway) and Islas Diego Ramirez (Chile) One of the more frequently visited island groups is the Falkland Islands/Islas Malvinas, partly because it is occasionally a changeover location for passengers and the start of following itineraries.

\section{TOURISM TRENDS AND STATISTICS}

The numbers of tourists annually have increased gradually, with some 37500 in the 2006-2007 season visiting Antarctica, of which approximately 25000 landed on the continent, and 8000 either over-flew or cruised only. In the 2005-2006 season, for comparison, somewhat more landed in Antarctica, however, and some 6000 visited the remote sub-Antarctic islands in about 40 vessels. Figure 1 summarises the annual figures and trends in tourist numbers from 1992-1993 through 2006-2007 (approx. 29 500, for those who landed only), as well as projections made for 2007-2008. Estimates of the total number of tourists for 2007-2008, including landings and other categories, total some 44000 (see also Landau \& Splettstoesser 2005, Table 12.1). The total figures for each season can be broken down into the type of tourism conducted. For example, not all tourists step ashore on land, many are included in over-flights without landings, and others are on cruise-only itineraries without landings (table 1).

IAATO has not maintained statistics on visits to subAntarctic islands to date, but IAATO's present organisation and infrastructure could readily be modified to incorporate those areas into the database. It is presently not a requirement of Treaty parties to maintain these data, but parties that govern several islands under jurisdiction maintain statistics for tour visits.

\section{Tourist visits to sub-Antarctic islands}

Figures for numbers of tourists visiting sub-Antarctic islands are not conveniently summarised, perhaps because of the lack of a central coordinating organisation such as IAATO. Some data from recently published literature are as follows.

\section{South Georgia}

Modern-day tourism began in South Georgia in 1970, with regular visits in the 1970 s and 1980s. Poncet \& Crosbie (2005) provided information on early tourism to the island, culminating in more than 40 ships each season carrying some 3500 passengers. Snyder \& Stonehouse (2007) tabulated tourist visits for the period 1991-2006, showing 11 ship visits in 1991-1992 to as many as 49 ships (plus 28 yachts) in 2005-2006, for a total of 5436 passengers in that season, not counting staff and crew.

\section{New Zealand's southern islands}

These islands are relatively convenient to visit because they are often on itineraries for tour vessels that visit Antarctica. Dedicated tourism visits began in 1968, and during the following 20 years some 1300 tourists are estimated to have visited, and in the five years following that a further 


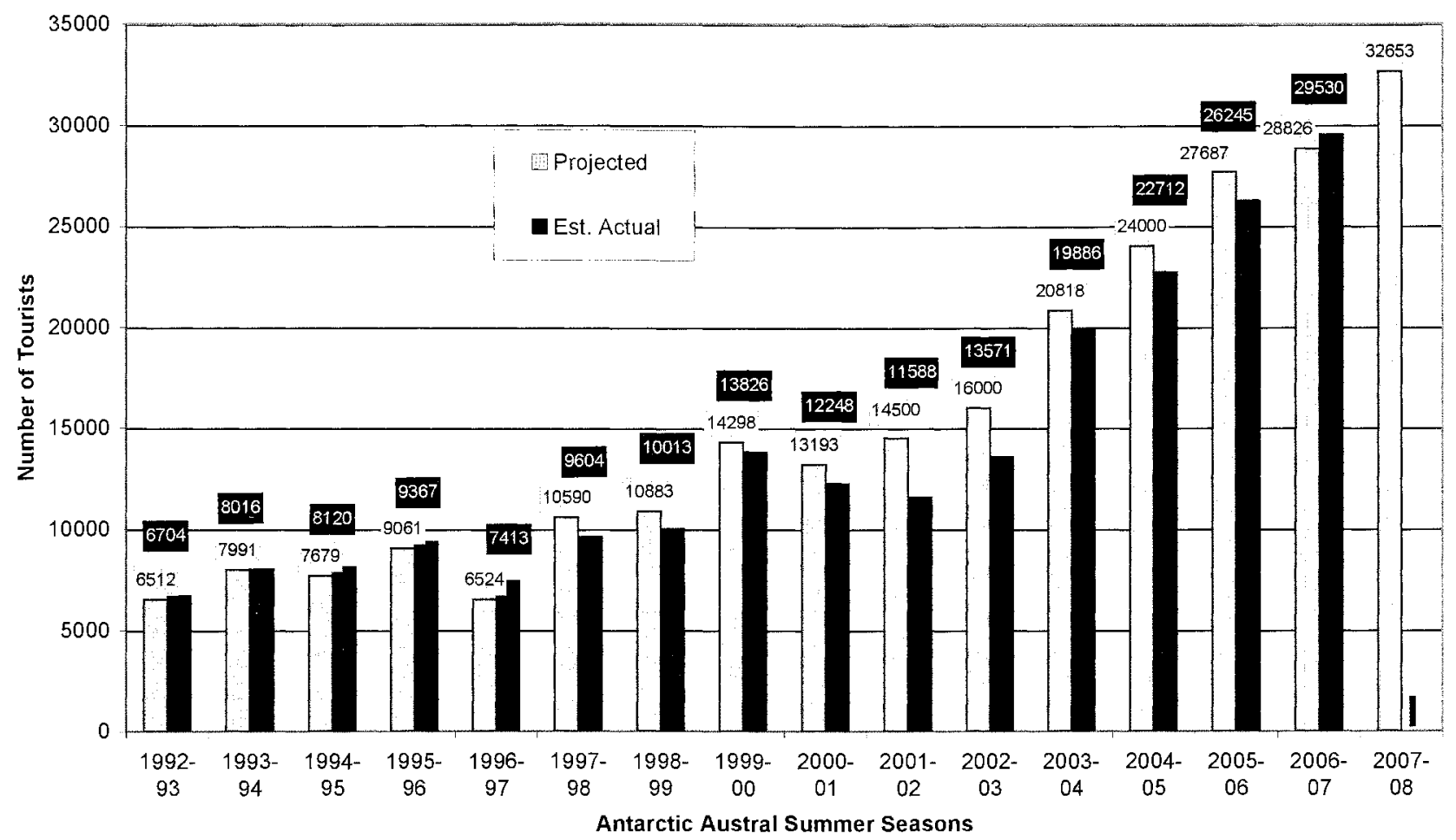

FIG. 1 - 1992-2007 Antarctic tourist trends: landed (includes ship and land-based passenger numbers. 1997-98 onwards includes some commercial yacht activity).

TABLE 1

Total visitor passenger estimates for the 2006-2007 season ${ }^{1}$

\begin{tabular}{lr}
\hline Type of tourism & Numbers \\
\hline Seaborne traditional tourism (with landings) & 28448 \\
Seaborne tourism cruise-only (no landing) & 6930 \\
Air/cruise & 174 \\
Air/land-based "traditional" tourism & 908 \\
Over-flights (no landing) & 1046 \\
Total & 37506 \\
\hline
\end{tabular}

1 From IAATO (2007).

1550 tourists landed (Tracey 2007). Due to high demand in 1991-2001 a seasonal limit on visitor numbers was set at 600 .

\section{Macquarie Island}

The first tourist visit to the island was in 1971 , and subsequent visits, occurring annually from 1992-2003, are a part of itineraries for Antarctica-bound vessels, which may include New Zealand's southern islands. Tourist landings take place at two sites, with small-boat cruising at another. Present guidelines limit numbers to 750 visitors each season, although in no season have they exceeded 560 (Tracey 2007).

\section{Heard Island}

Only three visits by tourist ships are recorded $(1992,1997$ and 2002) and five small private expeditions (Tracey 2007). Difficulty of access and stormy weather are deterrents to tourism, although in 1992 one helicopter flight was made to a shore-based research group to deliver mail and provisions, and later in that season, a landing was made by Zodiac at another location for the same purpose. In the first instance, three passengers got ashore, and in the second, one passenger plus ship staff. In 1997, helicopters were used to transport passengers ashore at Atlas Cove and most, if not all, of the ship's 90-100 passengers got ashore (1992 and 1997 information: J. Splettstoesser pers. comm. 2007). Since 1997 ships have visited Heard Island but IAATO has not kept specific numbers of visits.

\section{Tristan da Cunha group}

Tour ships have visited Tristan da Cunha almost annually since the 1970s, landing on the unprotected beach. But visits have taken place more frequently since a breakwater was constructed in 1967. Nearby Nightingale Island also receives visitors, escorted by Tristan inhabitants.

\section{Îles Crozet and Îles Kerguelen}

With the introduction of Russian icebreakers for use in Antarctic tourism in the 1992-1993 season, several subAntarctic islands have been visited, some annually. In the 1992-1993 austral summer, Îles Crozet (once) and Îles Kerguelen (twice) were visited, each time with about 80-90 passengers. The French stations were visited each time. They were visited again in the 1997-1998 summer, with about 95 passengers on each visit. Subsequent visits have taken place since 1998 but IAATO has not collected statistics. 


\section{St Paul Island and Amsterdam Island}

Both islands were visited in January 1993, St Paul by about 80 passengers, and Amsterdam by ship staff only on a single helicopter flight to the French station under foggy conditions that nearly aborted the visit (J. Splettstoesser pers. comm. 2007).

\section{South Sandwich Islands}

This island group was visited nearly annually beginning in the early 1990 s by a Russian icebreaker, and in later years by small expedition vessels. Two cruises took place each summer and within five or six seasons, five islands out of the 11 main islands were visited by tourists, either by Zodiac landings or helicopter, or both. Approximately 80-90 passengers were on each icebreaker cruise, although not all got ashore because of threatening sea conditions ( $J$. Splettstoesser pers. comm 2007).

\section{PROJECTIONS FOR ANTARCTIC TOURISM}

Projections for tourism in Antarctica show a gradual increase in numbers of visitors. Specialised management techniques and strategies are required by specialised forms of tourism, such as adventure tourism, to maintain environmentally-safe activities. The growth in numbers can be viewed as a trend but these increased numbers are not necessarily related to environmental impacts. These trends can be used to increase our understanding of tourism in general, as well as the management strategies and protective mechanisms required. Since organised tourism began in Antarctica in the 1970s, there has been no significant evidence of the cumulative impact on the environment of more than a minor or transitory nature. This level of impact has been determined from observations of experienced expedition staff, as well as government and other observers on cruises. These data are held by IAATO. The advantage of the tourist ship as the hotel is seen as a major factor in this regard.

Statistics collected by IAATO for tourism include the following: numbers of passengers; numbers of crew; nationalities of the above individuals; numbers and names of vessels and their registrations; size and type of vessels and aircraft; numbers of land-based tourists (not operators); and activities such as skiing, hiking, climbing, camping, SCUBA diving and small boat (Zodiac, Naiad, Polar Cirkle) cruising, landings, kayaking and hovercraft (IAATO 2007a).

With the increasing numbers of tourists the numbers of tour operators and ships has increased. The sizes and types of vessels vary depending on the operator, and include both ice-strengthened and non-ice-strengthened ships, icebreakers, yachts, and passenger capacities of about $40-50$ for smaller vessels to as many as 3000 for one of the larger ones, the latter conducting cruise-only operations. Because of the restriction on landings, larger ships agree not to land passengers in accordance with IAATO bylaws. As the number of vessels and tourists has increased, so has the industry's knowledge. And the sophistication of its operational procedures has evolved in response to the variety of specialised forms of tourism.

Land-based tourism, some of it conducted from tour vessels, includes camping, mountaineering, skiing and diving, and a temporary summer facility in the interior of Antarctica, at Patriot Hills in the Ellsworth Mountains, allows adventurers to be flown to the South Pole, or ski to it from Patriot Hills, as well as to visit Emperor Penguin colonies for stays of a week or more.

\section{HOW IT WORKS}

The collective experience of the current tour operator community (in total some 1500 years) over a period of some 35 actual years is a major factor in determining how and why the system works, with major attention given to preservation of the environment. As part of IAATO's original organisation, bylaws were compiled to identify the organisation's objectives and specify instructions and guidelines for operation, many of them related to Treaty Recommendation XVIII-1 from the Kyoto ATCM in 1994 (Antarctic Treaty Consultative Meeting 1994).

Membership categories were added to the bylaws to accommodate the increase in the numbers of vessels and their types, together with site guidelines specifying the numbers and sizes of ships permitted to visit locations to avoid over-visitation and potential impact on the wildlife. The limit of no more than 100 passengers ashore at any one place at any one time remains a guideline for any landings, together with a staff to passenger ratio of 1:20 while ashore. The basic guideline of IAATO's form of operation for its members remains: "To Advocate, Promote and Practise Safe and Environmentally Responsible Private-Sector Travel to Antarctica" (IAATO 2007a). These intentions remain the same wherever IAATO members operate, not only in Antarctica and the sub-Antarctic islands of New Zealand and Australia north of the Antarctic Treaty area, but also other southerly areas in their operations, such as South Georgia, South Sandwich Islands, Falkland Islands/Islas Malvinas. Many of the same IAATO member-operators also have comparable cruises in the Arctic and sub-Arctic, and observe the same guidelines and bylaws. A strong educational focus remains as a major theme of tour vessel operations

\section{MANAGEMENT INITIATIVES}

Examples of IAATO management initiatives in recent years to address the growth of tourism and required precautions include the following relevant to tourism in Antarctica and the sub-Antarctic islands.

\section{Ship-scheduler and vessel call data}

In order to organise ship operations better and more efficiently, an online Ship-Scheduler plan was developed for operators to provide their choices of sites on a pre-assigned date and a first-come first-served basis to avoid overcrowding of sites. While pre-scheduling has almost always been part of IAATO's operational procedures the online option has greatly enhanced the organisation's ability to manage tourism and landings. Vessel contact information is updated each year and as needed to ensure that ships are in daily contact with each other for itinerary coordination and emergency contingency planning. There are IAATO mandatory procedures for ships to coordinate with one another.

\section{Emergency medical evacuation response}

A Vessel Data Base was developed to provide vessel and company information in order to assure preparedness for possible emergency situations. An Emergency Medical 
Evacuation Response (EMER) was developed to account for medical emergencies.

\section{Improved operating database}

Hydrographic charting has become a normal activity for all tour vessels in little-known areas in an effort to improve charts. Other ship-borne procedures provided for tour vessels include a restriction on ballast-water release in the Antarctic Treaty area, and improved communications among all operators.

\section{Wildlife watching guidelines}

Procedures related to wildlife include Marine Wildlife Watching Guidelines, a parallel of that in place for wildlife on land, and include guidelines, for example, on safe distances from birds.

\section{Alien species}

An important aspect of IAATO guidelines is concern about the introduction of alien species. Guidelines covering this have been in place since IAATO's eleventh Annual General Meeting in Hobart, Tasmania (2000) and consist of boot and clothing decontamination guidelines, briefings to passengers and crew on translocation of diseases, procedures on boot-washing stations on ships and ashore, and the use of Virkon or equivalent disinfectant solution for washing. This is a particularly important procedure for all visitors to Antarctica to follow because of itineraries that include subAntarctic islands where seeds and related material might adhere to clothing and boots and possibly be introduced into Antarctica.

\section{Accreditation and auditing}

Accreditation and auditing procedures are under development in order to illustrate that what LAATO says it does can actually be demonstrated in a transparent manner. An observer program exists on ships to oversee operational activities including passenger and crew briefings, boot-washing procedures to prevent introduction of alien organisms into the Treaty Area and between shore visits, and other precautions. The observer program also contributes to information about possible minor or transitory environmental impacts.

\section{THE LEGACY OF IAATO}

IAATO has proven itself to be a successful manager of Antarctic tourism as a result of many of its initiatives, and by exhibiting a non-harmful presence in Antarctica. Support for these contentions has been provided by Treaty Party delegates in Antarctic Treaty Consultative Meetings. Details of management are removed from Treaty Party direct involvement, (i.e., IAATO is self-managing) but the parties are welcome to oversee the process and act accordingly when new regulations or procedures are required. Treaty parties are welcome to regulate tourism, and endorse the proactive approach that IAATO has taken in managing tourism. Continuing dialogue is an important part of this process.

The contribution of IAATO to the sub-Antarctic and Antarctic is illustrated in the following activities.

\section{Science-assisted logistics}

Transport of science/support personnel to and from stations and/or field sites - the "Ships of Opportunity" advantage of tour ships that visit many places in the sub-Antarctic and Antarctic that Treaty Party vessels might visit. About 100 science and support personnel per year are transported, many of them in the Ross Sea sector, and, for example, to and from Macquarie Island and Heard Island. Personnel were also transported to Campbell Island when the station was occupied. Tourism, rather than viewing itself as an entity completely isolated from science and research in Antarctica (the mandate stated in the Antarctic Treaty), has adopted and developed a longstanding outreach policy of assisting science.

\section{Charitable assistance}

IAATO member companies and their passengers contribute annually towards a number of charitable organisations, such as Save the Albatross Campaign, Antarctic Heritage Trusts for UK huts in the Antarctic Peninsula area and New Zealand huts in the Ross Sea sector, Grytviken Whaling Museum, Orca Project, American Bird Conservancy, Oceanites, and Birdlife International - Albatross. Donations of some U\$\$350000 were contributed in the 2005-2006 austral summer.

Donations raised through the charging of passenger fees in the sub-Antarctic islands of New Zealand and Macquarie Island provide the means to improve the facilities on the islands and assist towards management expenses by their respective governments. Boardwalks on Campbell Island and viewing platforms on Macquarie Island are tangible examples of how some of those funds are used. Mawson's Hut at Commonwealth Bay is also a major target of contributions for those who realise the need to preserve these historic records of earlier exploration and science.

\section{Ambassadors}

Perhaps less tangible but still effective is the principle that passengers who visit the sub-Antarctic and Antarctic can become "ambassadors", taking back with them a record of the majesty of this remote region and what it offers in wildlife, and the need for overall protection. Those philosophies are often reflected later in lobbying for legislation to protect Antarctica, further donations towards worthy causes, and the like.

\section{Partnership with Treaty parties and related organisations}

LAATO believes in the philosophy that creative and successful work can be accomplished between the science community and tourism by continuing dialogue with Treaty parties, the Council of Managers of National Antarctic Programs (COMNAP), and the Scientific Committee on Antarctic Research (SCAR), providing input at ATCMs in its Expert Status category. Co-operation with international agencies such as the International Hydrographic OrganizationHydrographic Committee on Antarctica ( IHO-HCA) in the improvement of charting for safe navigation is also seen as important.

\section{FUTURE OF IAATO AND POTENTIAL CONCERNS}

Although the relationship between IAATO, governments responsible for the management of the sub-Antarctic islands and the Antarctic Treaty parties has been relatively smooth, and is improving, there are occasional inconsistencies in government interpretations of tourism management. In some cases governments adopt the principle that what has been proper for management of its own territory and national parks, for instance, should be proper for management of 
tourism in Antarctica. A closer working relationship could benefit the long-term effectiveness of managing remote areas. Discussions are necessary between all stakeholders and are needed in the quest to find compromises, or to direct useful efforts towards a common working objective.

Media concerns are another facet of the tour industry; incidents can sometimes be reported erroneously or blown out of proportion. Some journalists are prone to seize on a minor event and expand on it to illustrate inaccuracies or concerns in a manner that is not realistic. The consequence is often that tourism is presented as unregulated or poorly managed. Self-imposed guidelines have been adequately developed and fully adhered to since 1991 when IAATO was formed (Splettstoesser \& Folks 1994, Splettstoesser 1996).

IAA'TO is concerned about non-member operators. LAATO will continue to encourage any operators not presently members of IAATO to join. The need for communication and cooperation between operators working in polar regions is paramount. Operators who are newcomers to the subAntarctic islands and Antarctica need to work together and take account of the permit procedures of their native countries in addition to those agreed by the Antarctic Treaty. They need to carry out operational procedures necessary for visits not only to the Antarctic continent but also the subAntarctic islands, where wildlife and vegetation, as well as alien organisms, are consistently major concerns

Governments that administer Antarctic islands should be urged to exchange experiences and information on tourism management. Close links should be established among tourist operators, tour company associations, island management authorities, and the scientific and conservation community, to promote responsible and safe operations (International Union for the Conservation of Nature 1992).

Future challenges and identified tasks are as follows and require further discussion amongst appropriate parties.

- Concern that an increase in tourism causes environmental impact. Does it? Could it? If so, to avoid such impacts requires a close working relationship between all stakeholders. Bridging these efforts needs to be further identified.

- Should science be involved in decision-making, for example in determining accurate information on the possibility that cumulative impacts occur in wildlife areas visited by tourists on a frequent basis? Without science backing, are any regulatory decisions in this regard credible?

- Different landing sites need different management strategies. Identify particular areas that could be of potential risk and work cooperatively to ensure that best practices are identified.

- What lessons can be learned from management practices in effect for many years in sub-Antarctic islands that can be applied to Antarctic Treaty areas visited by tourists?

- Costs of management of remote areas increase annually. Creative ways of ensuring protection must be examined without incurring enormous costs if other alternatives are possible.

- Ensure, where possible, that environmental considerations prevail over political agendas. This could perhaps be one of the most difficult areas to address.

- What can be learned from management plans at each of the sub-Antarctic island groups and where are the management gaps?

- Would a global and or localised environmental steering group be useful for decision-making?

- Would a website discussion forum be useful to examine management procedures in sub-Antarctic islands and enhance existing management plans?

\section{CONCLUSION}

IAATO has managed the tourism industry in Antarctica and the sub-Antarctic islands successfully for the 15 years of its existence. The organisation wrote and implemented numerous guidelines and operating procedures that were developed by its members over many years, all with protection of the environment in mind As a result, little, if any, discernible environmental impact is evident.

The procedures used presently extend to other areas (Arctic, sub-Arctic, Amazon, all other continents) thus emphasising protection of the environment. All IAATO activities are reported annually and transparently and Antarctic Treaty parties look to IAATO for discussions that assist in the resolution of tourism issues.

IAATO is committed to the long-term protection of Antarctica, the sub-Antarctic islands and associated and dependent ecosystems and looks forward to future cooperation wherever and whenever possible, with respect to activities in not only the Antarctic Treaty area, but also in the sub-Antarctic islands

\section{ACKNOWLEDGEMENTS}

IAATO would like to thank Sir Guy Green for his life-long passion and dedication towards protecting one of the most incredible parts of the world, the sub-Antarctic islands and Antarctica, Professor Pat Quilty and Dr Patricia Selkirk for their patience and contributions towards organising the speakers' presentations for publication, and Antarctica Tasmania (Ben Galbraith and Heather Glidden) for organising this very important conference on the sub-Antarctic. Government organisations of this nature play an integral role in protecting the wild places which are vitally important to the health of the planet. This paper and its presentation at the meeting of the sub-Antarctic islands in Hobart has benefited from contributions by many IAATO members, but in particular from John Splettstoesser, Advisor to IAATO.

\section{REFERENCES}

Antarctic Treaty Consultative Meeting 1994: Recommendation XVIII-1: Tourism and non-governmental activities (includes "Guidance for visitors to the Antarctic" and "Guidance for those organising and conducting tourism and non-governmental activities in the Antarctic").

IAATO 2007a: Organisation website at www.iaato.org. Accessed September 2007.

IAATO 2007b: XXX Antarcric Treaty Consultative Meeting, IP 121 - IAATO Overview of Antarctic tourism, 2006-2007 Antarctic Season: 23 pp.

International Union for the Conservation of Nature 1992: Conservation of Polar Regions \#2 Progress in the Conservation of the sub-Antarctic Islands. Proceedings of the SCAR/IUCN workshop on protection, research and management of sub-Antarctic islands. Paimpont, France, 22-29 April 2992: 225 pp.

Landau, D. \& Splettstoesser, J. 2007: Antarctic tourism: what 
are the limits? In Snyder, J.M. \& Stonehouse, B. (eds): Prospects for Polar Tourism. CABI, Oxon, UK: 197-209.

Poncet, S. \& Crosbie, K. 2005: A Visitor's Guide to South Georgia. WildGuides Ltd., Maidenhead, UK: 179 pp.

Snyder, J.M. \& Stonehouse, B. 2007: Tourism on South Georgia: a case for multiple resource management. In Snyder, J.M. \& Stonehouse, B. (eds): Prospects for Polar Tourism. CABI, Oxon, UK: 247-262.

Splettstoesser, J. 2000: IAATO's stewardship of the Antarctic environment: a history of tour operators' concern for a vulnerable part of the world. International Journal of Tourism Research 2(1): 47-55.
Splettstoesser, J. 1996: Education of visitors to Antarctica. In Dingwell, P.R. \& Walton, D.W.H. (eds): Opportunities for Antarctic Environmental Education and Training. Proceedings of the SCAR/IUCN workshop, Gorizia, Italy, 26-29 April 2003: 75-86.

Splettstoesser, J. \& Folks, M.C. 1994: Environmental guidelines for tourism in Antartica. Annals of Tourism Research 21(2): 231-244.

Tracey, P. 2007: Tourism management on the southern oceanic islands. In Snyder, J.M. \& Stonehouse, B. (eds), Prospects for Polar Tourism. CABI, Oxon, UK: 263-284.

(accepted 24 September 2007) 